\title{
Affective Spectrum Disorders and Role of Serotonergic System of the Brain
}

\author{
Ivana P. Timotijević ${ }^{1}$, Mirjana M. Todorović ${ }^{2}$, Katarina B. Crnic ${ }^{2}$, \\ Srdjan Z. Marković ${ }^{3}$, Dragana A. Kastratović ${ }^{4}$ \\ ${ }^{1}$ «Euromedik» Policlinics, Medical faculty, University in Belgrade, Serbia \\ ${ }^{2}$ Special psychiatric ordination «Ramah», Belgrade, Serbia \\ ${ }^{3}$ Medical faculty, University in Belgrade, Serbia \\ ${ }^{4}$ Clinical Center of Sebia, Belgrade, Serbia
}

\section{SUMMARY}

Affective spectrum disorders include mood and anxiety disorders, whereas the term functional somatic syndromes describes disorders in which the main symptom is chronic pain, with no pathognomonic tissue damage, such as fibromyalgia, irritable colon, tension headache. Pain as a symptom is often present in patients with depression and anxiety, and similarly, depressed mood, anxiety and other psychiatric symptoms are common in patients with functional somatic syndromes. This explains attitudes that affective disorders and functional somatic syndromes should be found along the same spectrum, due to a similar neurobiochemicalmehanism and dysfunction of these CNS structures and neurotransmitter systems, which lead to similar symptoms in both groups. The symptoms of affective disorders, including somatic are associated with serotonin and serotonergic transmission in the CNS. The existence of depressive and anxiety disorders, such as fatigue, sleep disorders, cognitive disorders, depressed mood, anxiety, and functional somatic syndromes code indicate a similar mechanism of origin. Hypothesis of central neuropathic pain explains the possibility of the descending inhibitory pain mechanisms, including serotonergic and noradrenergic projections and their receptors. Central suprasegmental senzitization in nociceptive pathways, also at the level of the thalamus and the sensory cortex, trigered by an emotional stressors can cause painful symptoms in both groups of disorders. Serotonergic and noradrenergic pathways and voltage sensitive channels of their receptors are included in the mechanism.

Modern psychopharmacology can no longer ignore the existence of painful symptoms in affective disorder or depressive and anxiety symptoms in functional somatic syndromes and their treatment can improve. Therapeutic effects of SSRI and SNRI antidepressants and alpha 2 delta ligands for all kinds of painful symptoms in affective disorders - serotonergic spectrum is expected, due to the impact of the dysfunctional neurotransmission in specific regions of the CNS, increasing the efficiency of information processing and reduction of symptoms.

Keywords: affective disorders, chronic pain, extended affective spectrum, CNS serotonergic system 


\section{INTRODUCTION}

Affective disorders include a wide range of entities, symptoms and syndromes, which are based on the expression of emotion in the broadest clinical sense. The psychological dynamics is complex and specific to each disorder, but a common denominator lies in biohemcal - neuro mechanisms, joint structures of the CNS and their receptor - transmitter systems. Biological theories of affective disorders in the center of events put limbic structures of the brain, with all their connections with other higher and lower structures of the CNS, while serotonin, serotonergic transmission and serotonergic system in general, or its dysfunction are dominant factors in etiopathogenesis of all affective variabilities [1]. Also, the different part of the symptomatology of the various entities associated with dysfunction in serotonergic transmission of any routes that connect the parts of the limbic system, as the nuclei amygdala, hypothalamus and the hippocampus, whether it is in pathways which connect limbic system to the prefrontal cortex,basal ganglia, raphe nuclei and other nucleuses in medulla oblongata,motoneurons in the frontal and lateral horns of the spinal cord. By the same logic, psychopharmacutics acting on serotonergic transmission in specific regions of the CNS dysfunctional increase the efficiency of information processes in their pathways leading to the reduction of symptoms of affective disorders. Common ethiopathogenetic grounds justifyes attitudes about setting up the many different symptoms of affective disorders in the same continuum of affective spectrum, which aligns diagnostic and therapeutic attitudes $[2,3]$.

\section{SOMATIC SYMPTOMS AND SYNDROMES}

It is generally known that the clinical symptoms of affective disorders, particularly depression and anxiety, often includes a variety of somatic symptoms, which are often not discriminatory according to current diagnostic classifications, although they sometimes dominate the clinical picture, they are not recognized and discredit the proper diagnosis and treatment. They are often predictors of theraporesistant forms and the most common are residual symptoms - up to $76 \%$ which have the negative impact on quality of life and social functionality. Symp- toms may belong to different organ systems and often include a variety of pain syndromes. Chronic pain as a symptom of affective disorder is a reality which patients face and cope with, while psychopharmacology often overlookes it and is engaged in the so-called "core" symptoms or primerily psychic functions disorders $[4,5]$.

In another specific group of disorders, which are called by generic name functional somatic syndromes, covering such disorders as fibromyalgia, chronic fatigue, irritable colon, tension and migraine headaches, chronic pain is the predominant symptom, in the absence of pathognomonic tissue damage. In addition, various psychological symptoms in a large percentage of cases are present - depression, anxiety, sleep disorders, cognitive disorders. Problems of proper diagnosis and timely and effective treatment are important in this group of disorders [6].

\section{CENTRAL NEUROPHATIC PAIN TERM}

There are more and more experts who explore possible common grounds and reasons for the occurrence of chronic pain syndromes in these groups, at first glance the various disorders. It is assumed that similar neuro mechanism connects them, the involvement of the same brain structures and their neurotransmitting system [7].

As the pain in both groups of disorders does not appear clearly and defined lesion tissue or organs, the similarity is established with neurophatic pain genesis ("phantomic limb", diabetic neurophaty) in which tissue lesion existed and is cured but painful irritations and pain perceptions still exist usually along with intensive pain and chronificacion,as well as inefficiency of usual pain therapy. Therefore, the theory of central neuropathic pain has been accepted as an explanation of the occurrence of painful symptoms in affective disorders and functional somatic syndromes associated with psychical symptoms [3]. Mechanism of central neuropathic activity is in many ways a theoretical process.

\section{CENTRAL SEGMENTAL SENTISIZATION THEORY}

One group of theory indicates that is responsible insufficiency of descending inhibitory 
mechanism of pain due to lack of monoamines and their receptors at the level of the segments of the spinal cord and the phenomenon of sensitization to painful stimuli. Nociceptive stimuli from visceral organs, muscles and joints during movement and other irrelevant painful stimuli are veiled and imperceptive by this mechanism, allowing normal functioning $[3,7]$. The descending inhibitory mechanism originates and is regulated mainly from the periaqueductal gray in medulla oblongata, where he acquired projections of nociceptive pathways and limbic structures and firing down towards the nuclei in the rostral ventromedial medulla and from there to the segments of the spinal cord.In some fibers of the pathway are released endorphins and encephalin that affect the presynaptic opioid receptors and inhibit the transmission with nociceptive afferent neurons.Another important mechanism is the descending inhibitory spinal noradrenergic path, which begins in locus coeruleus and innervates alpha- 2 adrenergic receptors.

The next descending inhibitory mechanism is represented by spinal serotonergic pathways, which origines from the raphe nuclei in the medulla to the postsynaptic 5-HT $1 \mathrm{~B}$ and 5-HT1D receptor and blocks the transmission of nociceptive impulses. Serotonergic mechanism may in certain situations facilitate and enhance the transmission of painful stimuli.

Insufficiency of monoamine action and failed descendent inhibition in nociceptive pathways function leads to the tightening of perception of generally irrelevant nociceptive stimulus from the body, and with extra additional mechanism of sensitization to pain, leads to the phenomenon of chronic pain, where under threshhold irritations cause significant perception of repetitive or constant pain.Sensitization of pain involves a complex and closed-circuit events in the CNS, starting from certain segments of the spinal cord to higher structures in nociceptive path, which involves a series of molecular, synaptic and the structural changes and establish the process of "learning" painful experience [8].

\section{CENTRA SUPRASEGMENTAL SENTISIZATION THEORY}

In addition to the theory of central segmental sensitization, there are theories of suprasegmental central sentisization, where it is as- sumed disorder/damage to brain structures of nociceptive pathways above the level of the spinal cord and medulla $[3,8]$.

It is assumed that the presynaptic membrane receptors lead to phosphorylation and permanent opening of sodium and calcium channels - the phenomenon of "gate open", with increased activity of the postsynaptic neurons, when the minimum irritation causes an abundant synaptic transmission. Trigger for this mechanism may in these higher structures CNS-thalamus, sensory cortex, come from the CNS itself, inside, without the existence of stimuli from the periphery. Stress or emotional trauma can be the discriminant irritation inside, which will establish the sensitization and lead to the experience of pain, which will be associated with psychological symptoms. Relation of stress and emotion, the limbic part of the CNS and higher brain structures involved in pain perception, realized serotonergic projections from the amygdala to the thalamus, and the amygdala to the raphe nuclei in the medulla oblongata, so the possibility of affecting various parts of the nociceptive times, transmission and pain perception is important [2].

In some studies is confirmed the importance of NMDA glutamate receptors in the mediation of transmission nociceptive impulses through non-myelinated $\mathrm{C}$ fibers and their association with HPA axis.

\section{EXTENDED AFFECTIVE SPECTRUM AND THERAPEUTIC APPROACH}

It is clear that the influence of inefficient serotonergic and noradrenergic transmission in certain parts of the CNS in the development of depressive and anxiety disorders is established in biological theories of their etiopathogenesis, while the impact on the development of painful symptoms within these disorders and functional somatic syndromes are still investigating. However, modern psychopharmacology can no longer ignore their existence and can improve their treatment with drugs, based on the knowledge gained so far.

Many experts argue that the affective spectrum should be extended to functional somatic syndromes, because it would significantly enhance the capabilities of faster and more efficient diagnosis and treatment of all disorders in this continuum in order to achieve 
complete remission and improved quality of life of patients [3].

From the earlier considered mechanisms of the central neuropathic pain origin arise that efficient medication should mean improving disordered transmission in the frame of serotonergic and noradrenergic system, as well as psychopharmaca with predominant influence on the function of ionic channel of receptor cells.

Therefore, in the first line of treatment are SNRIs and SSRIs antidepressants and alpha 2 delta ligands (gabapentin and pregabalin) [9].

In the second line of treatment are TCA antidepressants and mirtazapine, which can be used in combination with SSRIs $[3,10]$.

As additional therapy in the treatment of certain theraporesistant symptoms such as fatigue and tiredness, modafinil may be used, bupropion, trazodone in sleep disorder, etc [11].

The need for cooperation with other specialists, dose individualization [12] and comprehensive, multidisciplinary treatment of painful symptoms and syndromes is emphasized, any diagnostic category they belong to, just to achieve the previously highlighted goals- complete remission of symptoms and improved quality of life for patients.

Although diagnostic criteria have not yet been standardized and treatment established, therapeutic utilitarian approach and focus of pharmacological actions towards hypothetically dysfunctional neural networks and their systems, the transmitter can be a useful and efficient approach [13].

\section{CONCLUSIONS}

Disorders of affective spectrum are well known and thoroughly studied in the light of the biological theory of their etiopathogenesis. Dysfunction of specific brain regions and disrupted transmission in complex neuronal circuits that connect them, are the cause of many symptoms along the continuum of the spectrum. Although they are not discriminatory for diagnosis, different somatic symptoms, and among them painful symptoms of various organs are common in clinical affective disorders. They complicate the process of disease, compromising the achievement of complete remission and in many cases they cause thraporesistance.
The focus of the study include functional somatic syndromes, such as fibromyalgia, chronic fatigue syndrome, irritable colon, headaches, wherein the chronic pain is a leading symptom, without defined lesion tissues or organs, often present with a variety of physiological symptoms. They are, as a rule, the problem of how to diagnose, and treat and significantly affect the social function of patients.

The idea of extended affective aspect of which, in addition to the typical affective disorders included a functional somatic syndromes, represent many experts. Theoretical assumptions and findings of modern psychopharmacology of possible common neurophysiological basis of pain syndromes and symptoms, with the presence of psychological symptoms can significantly improve their better grasp and treatment.

Theories of central neuropathic pain, crossing projections from the centers for emotion and nociceptive pathways at different levels of the CNS, with serotonergic dysfunction transmission and noradrenergic neuronal networks, which can be trigered by stress or emotional trauma, leading to the onset of symptoms are distinguished as key theories.

In the first line of treatment are proposed SNRIs and SSRIs antidepressants and alpha 2 delta ligands, which target just the places of disordered transmission of impulses, increase the efficiency of information processes and lead to a reduction of symptoms that are otherwise refractory to conventional therapy approach.

Openness to new knowledge and treatment can improve the results of treatment and quality of life of patients from both groups of disorders.

\section{REFERENCES}

1. Berger M, Gray JA, Roth BL. The expanded biology of serotonin. Annu Rev Med. 2009; 60:355-66.

2. Shin LM, Libezon I, The neurocircuitry of fear, stress and anxiety disorders. Neuropsychopharmacology. 2010; 35(1): 196-91

3. Stahl SM. Essential psychopharmacology. 3rd ed. New York: Cambrige University Press;2008.

4. Rakic Ignjatovic A, Miljkovic B, Todorovic D, Timotijevic I, Pokrajac M. Moclobemide monotherapy vs combined therapy with valproic acid or carbamazepine in depressive patients; a pharmacokinetik interaction study. Br J Clin Pharmacol. 2009; 67(2): 199-208. 
5. Vezmar S, Miljkovic B, Vucicevic K, Timotijevic I, Prostran M, Todorovic Z, Pokrajac M. Pharmacocinetics and efficacy of fluvoxamine and amitryptiline in depression. J Pharmacol Sci. 2009 May;110(1):98-104.

6. Ignjatovic AR, Miljkovic B, Todorovic D, Timotijevic I, Pokrajac M. 2011. Evaluation of single-point sampling strategies for the estimationb of moclobemide exposure in depressive patients. J Clin Pharmacol. 2011;51(5): 661-71.

7. Rehm SE, Koroschetz J, Gockel U, Brosz M, Freynhagen R, Tölle TR, Baron R. A cross-sectional survey of 3035 patients with fibromyalgia: subgroups of patients with typical comorbidities and sensory symptom profiles. Rheumatology (Oxford). 2010 Jun;49(6):1146-52.

8. Van Tillburg MA, Spence NJ, Whitehead WE, Bangdiwala S, Goldston DB. Chronic pain in adolescents is associated with suicidal thughts and behaviors. J.Pain. 2011;12, 1032-9.

9. Markman JD, Dworkin RH. Ion Channel Targets and Treatment Efficacy in Neuropathic Pain. The Journal of Pain. 2006 Jan; 7(1), Suppl: S38-S47 .

10. Kroenke K, Bair MJ, Damush TM, Wu J, Hoke S, Sutherland J, Tu W. Optimized antidepressant therapy and pain self-management in primary care patients with depression and musculoskeletal pain: a randomized controlled trial. JAMA. 2009 May 27;301(20):2099-110.

11. Timotijevic I, Stankovic Z, Todorovic M, Markovic SZ, Kastratovic DA. Serotonergic organisation of the central nervous system. Psych Danub 2012; 24 (Suppl 3): 5326- 30

12. Jankovic SM, Timotijevic I, Mihajlovic GS, Djukic Dejanovic S. Comparison of two approaches to amitryptiline dose individualisation, 1999. Eur J Drug Matab Pharmacokinet 24(2), 163-8

13. Timotijević IP, Todorović MM, Crnić KB, Marković SZ, Kastratović DA. Serotonergic Antidepressants as Predictors of Depressive Disorders Treatment. Hospital Pharmacology. 2014; 1(1):27-32. www. hophonline.org 


\title{
Prošireni afektivni spektar i serotonergički sistem CNS
}

\author{
Ivana P. Timotijević ${ }^{1}$, Mirjana M. Todorović ${ }^{2}$ Katarina B. Crnic ${ }^{2}$, Srdjan Z. Markovićs, \\ Dragana A. Kastratović ${ }^{4}$ \\ ${ }^{1}$ «Euromedik» Poliklinika, Medicinski fakultet, Univerzitet u Beogradu, Srbija \\ ${ }^{2}$ Specijalistička psihijatrijska ordinacija «Ramah», Beograd, Srbija \\ ${ }^{3}$ Medicinski fakultet, Univerzitet u Beogradu, Srbija \\ ${ }^{4}$ Klinički centar Srbije, Beograd, Srbija.
}

\section{KRATAK SADRŽAJ}

Afektivni spektar uključuje poremećaje raspoloženja i anksiozne poremećaje, dok termin funkcionalni somatski sindromi opisuje poremećaje u kojima je hronični bol vodeći simptom, bez patognomoničnog oštećenja tkiva, kao što su fibromialgia, iritabilni kolon, tenziona glavobolja. Bol kao simptom je često prisutan kod pacijenata sa depresijom i anksioznosti, a slično tome, depresivno raspoloženje, anksioznost i drugi psihički simptomi su uobičajeni kod pacijenata sa funkcionalnim somatskim sindromima. To objašnjava stavove da bi afektivni poremećaji i funkcionalni somatski sindromi trebalo da se nađu duž istog spektra, zbog sličnog neurobiohemijskog mehanizma i disfunkcije istih struktura CNS i neurotransmiterskih sistema, koji dovode do sličnih simptoma u obe grupe.

Simptomi afektivnih poremećaja, uključujući i somatske su povezani sa serotoninom i serotonergičkom transmisijom u CNS. Postojanje depresivnih i anksioznih poremećaja, kao što su umor, poremećaji spavanja, kognitivne smetnje, depresivno raspoloženje, anksioznost, kod funkcionalnih somatskih sindroma ukazuje na sličan mehanizam nastanka. Hipoteze o centralnom neuropatskom bolu objašnjavaju mogućnost poremećaja descendentnog inhibitornog mehanizma za bol, uključujući serotonergičke i noradrenergičke projekcije i njihove receptore. Centralne suprasegmentne senzitizacije u nociceptivnim putevima, takođe, na nivou talamusa i senzornog korteksa, pokrenute emotivnim stresorima, mogu uzrokovati bolne simptome u obe grupe poremećaja. Serotonergičke i noradrenergičke neuronske mreže, kao i senzitivni jonski kanali njihovih receptora su uključeni u taj mehanizam.

Moderna psihofarmakologija ne može više ignorisati postojanje bolnih simptoma kod afektivnih poremećaja ili depresivne i anksiozne simptome kod funkcionalnih somatskih sindroma i može unaprediti njihov tretman. Terapijsko delovanje SNRI i SSRI antidepresiva i alfa 2 delta liganda za sve vrste bolnih simptoma kod poremećaja afektivnog - serotonergičkog spektra očekivano je, zbog uticaja na disfunkcionalnu neurotransmisiju u specifičnim regionima CNS, podizanja efikasnosti informacionih procesa i redukovanja simptoma.

Ključne reči: afektivni poremećaji, hronični bol, prošireni afektivni spektar, serotonergički sistem CNS 